\title{
Perceived Organisational Support and Organisational Commitment among Oil and Gas Offshore Employees in Malaysia
}

\author{
Ridwan Mokhtar \\ Arshad Ayub Graduate Business School, \\ Universiti Teknologi MARA (UiTM), Sabah Branch, Kota Kinabalu Campus, Malaysia \\ E-mail: drridwanmokhtar@gmail.com \\ Sylvia@ Nabila Azwa Ambad \\ Faculty of Business and Management, \\ Universiti Teknologi MARA (UiTM), Sabah Branch, Kota Kinabalu Campus, Malaysia \\ E-mail: nabilazwa@gmail.com
}

Sharifah Nurafizah Syed Annuar

Faculty of Business and Management,

Universiti Teknologi MARA (UiTM), Sabah Branch, Kota Kinabalu Campus, Malaysia

E-mail: shnurafizah@gmail.com

\author{
Nelson Lajuni (Corresponding author) \\ Faculty of Business, Economics and Accountancy, \\ Universiti Malaysia Sabah (UMS), Malaysia \\ E-mail:nlajuni@gmail.com
}

Received: Oct. 9, 2020 Accepted: Nov. 1, 2020 Online published: Nov. 4, 2020

doi:10.5296/ijhrs.v10i4.17914 URL: https://doi.org/10.5296/ijhrs.v10i4.17914 


\section{Abstract}

With the fast growth of business and rapid changes in the economic landscape, organisational commitment remains an important subject to be discussed in any part of an organisation. Thus, the present study examines the effects of perceived organisational support on organisational commitment among offshore employees in Malaysia. A study was conducted by distributing online questionnaire via Google Forms among offshore employees. A total of 246 completed responses were collected, and data collected were then analysed using PLS-SEM 3.3.2. The outcomes suggest that all dimensions of perceived organisational support have a significant relationship towards organisational commitment among offshore employees in Malaysia, except for supervisor support.

Keywords: organisational commitment, perceived organisational support, oil and gas, offshore

\section{Introduction}

For several decades' numerous studies on organisation commitment have been conducted. Organisational commitment refers to employees' sense of attachment and belonging that they feel towards the organisation (Newstrom, 2015). It reflects the commitment experience that stemmed from the daily work activities (Beardwell \& Thompson, 2014). There are three distinct types of organisational commitment: affective commitment, normative commitment, and continuous commitment. Affectively committed employees indicate they are emotionally attached to the organisation; continuance commitment is linked to the level of commitment whereby the employee feels it is costly to leave the organisation; and normative commitment refers to how much the employee feels obligated to stay in the organisation (Meyer \& Allen, 1991). So far, studies conducted are mostly related to the dimension of affective commitment. Moreover, there are less studies being conducted in the oil and gas industry in Malaysia context. Thus, this study would offer a fresh and clear perspective in Malaysia's context, specifically in the offshore environment. This study is exploratory in nature, which will investigate the relationship between perceived organisational support and organisational commitment dimensions.

\section{Literature Review}

\subsection{Organisational Commitment}

There have been many definitions of organisational commitment suggested by numerous authors since studies on organisational commitment started. For instance, Becker suggested that commitment emerges when one makes a side-bet based on the main activity (Becker, 1960). Organisational commitment is understood as individuals' willingness in rendering loyalty and energy to social systems, personality systems attachment to social relations, or self-expressive (Kanter, 1968). Also, organisational commitment is where organisational and individuals' goals become united or corresponded (Hall, Schneider, \& Nygren, 1970). Determining organisational commitment is assessing the correspondence between individuals and the organisation's beliefs and values (Swailes, 2002). Numerous studies had investigated on how organisational competitiveness and efficiency - in an institution, a company, or a 
political organisation - can be further improved; the researchers decided that workers' organisational commitment is a critical predictor to its successful performance (Farid, Izadi, Ismail, \& Alipour, 2015). The willingness of the employees to contribute to the goals of the organisation is known as organisational commitment. Employees' level of commitment level to stay with their organisation would increase if they are confident that they will grow together with their employer (Okpara, 2004). Another definition describes organisation commitment as an affective attachment of organisational values and goals to individuals' role values and goals, instrumental worth (Buchanan, 1974). Meanwhile, commitment behaviours refer to socially accepted behaviours and surpass normative and/or formal anticipations that linked to the object of commitment (Wiener \& Gechman, 1977). Despite the various definition, the earlier definitions are mostly focused on commitment-related behaviours, which has evolved to include the perspective of personal attitude. Attitudinal commitment usually consists of a reciprocity relationship; employees ascribe themselves to the organisation for payments or rewards from the organisation (March \& Simon, 1958). Organisational commitment is also being described as a psychological mindset of the workers who identified themselves with their organisation and reflected the need and desire, and/or a responsibility to preserve affiliation with the organisation (Allen \& Meyer, 1990; Blau \& Boal, 1987; George, Reed, Ballard, Colin, \& Fielding, 1993). Allen and Meyer (1990) conceptualised organisational commitment into three dimensions, namely normative commitment, affective commitment, and continuance commitment; the current study will adopt this definition.

\subsubsection{Affective Commitment}

This dimension is deemed an essential determinant of employees' willingness to remain with their organisation and support the organisational goals (Klein, Becker, \& Meyer, 2009; Meyer \& Allen, 1997). Employees display this type of commitment by remaining with their organisation voluntarily. They are not only emotionally attached but identified and deeply involved with the organisation. In a nutshell, affective commitment comprises individual characteristics, work experience, and organisational structure (Allen \& Meyer, 1990). Due to similar values, in this type of commitment, organisation and individuals are interacting positively (Shore \& Tetrick, 1991). A research carried out among workers of the prison revealed how employees' having autonomy or more control over their work environment leads to the weak effect of perceived organisational support on the level of affective commitment (Aubé, Rousseau, \& Morin, 2007). The control level of employees' feelings could be due to personality or the work design, allowing for more autonomy; hence, leading to employees' capability in performing their assigned tasks with minimal guidance or control from superiors or the management. Strong commitment employees want and need works; thus, they willingly remain with their organisations (Meyer, Allen, \& Smith, 1993). Studies that focused on employees' work experience posited that when workers found their work experience and expectation reliable, and all the basic needs fulfilled, they were likely to have a stronger affective attachment towards their organisation (Dunham, Grube, \& Castañeda, 1994; Hackett, Bycio, \& Hausadorf, 1994; Meyer et al., 1993). Accordingly, in the presence of high level of work autonomy, support strategies should be the organisations top priority 
while hoping that the strategies would motivate and boost workers' affective commitment (Aubé et al., 2007; Aggarwal-Gupta, Vohra, \& Bathnagar, 2010). Employees having stronger affective commitment were more adaptive to changes within the organisation because they were more involved and attached emotionally to the organisation, provided the change initiatives were deemed advantageous to the organisation (Yousef, 2000). Evidently, organisational commitment is a reciprocating relationship between organisation and employees, while commitment is the outcome of the effort of employees, in return for rewards, either symbolic or material (Eisenberger, Huntington, Hutchison, \& Sowa, 1986). Consequently, employees with a high level of perceived organisational support are expected to display a high level of affective commitment towards their organisations as well.

\subsubsection{Normative Commitment}

Employees' obligation to remain with their employment is known as normative commitment (Allen \& Meyer, 1990). This type of commitment suggests that employees' strong normative commitment lead to their decision to stay with an organisation as it is the "right and moral" thing to do (Meyer \& Allen, 1991). According to Wiener and Gechman (1977), the development of this type of commitment began at early socialisation with their family and culture, and when they initially joined the organisation. Likewise, the "psychological contract" between organisations and employees might lead to normative commitment (Roussenau, 1995). Another view on normative commitment is that it is the result of feeling indebtedness to the organisation because of the rewards awarded to employees (Scholl, 1981). A study conducted in the public sector found a negative relationship between normative commitment and uncertainty and conflicting role. Workers with high levels of uncertainty and role conflict tended to possess a lesser emotional attachment, do not share the organisational goals and values or feeling less obligated to stay in the public sector (Addae, Praveen Parboteeah, \& Velinor, 2008). However, a study by San Martín (2008) revealed that solidarity and satisfaction somewhat affected the employees' normative commitment; the sense of fulfilment in work and responsibilities showed a significant negative influence on normative commitment. A plausible explanation is that employees who were satisfied with their work would feel more connected to the organisation and less obligated to work; hence, feeling more laid back and thinking minimal effort is required to keep a good working relationship (San Martín, 2008).

\subsubsection{Continuance Commitment}

Continuance commitment complements affective organisational commitment. This commitment thought employees remain with a company because they do not want to lose the benefits or accept wage reduction and unable to get a job replacement (Murray, Gregoire, \& Downey, 1991). This type of commitment is evidenced when employees choose to stick with the organisation out of necessity (Allen \& Meyer, 1990). This feeling of need could be due to employees' advancement; a tenure and employees' acknowledgement of their contribution to the organisation in terms of effort and time, and the increased cost of leaving the organisation (Currie \& Dollery, 2006). A few studies showed the relationship between unceasing commitment and tenure and age (Currie \& Dollery, 2006; Kwantes, 2009). When employees 
advanced in their employment, they would consider their invested effort, time, and knowledge, leading to a perception of the increased cost of leaving the organisation (Currie \& Dollery, 2006). Thus, given that perceived cost-benefit analysis is the base for continuous commitment, it is unlikely that this type of commitment would lead to high job performance (Iles, Forster, \& Tinline, 1996). However, another research showed that higher performance is expected when the perceived cost of employment termination is high (Suliman \& Iles, 2000). In a nutshell, employees would do their best or do what needs to be done to assure their spot in an organisation, especially during an economic downturn, for their survival.

\subsection{Perceived Organisational Support}

Perceived organisational support refers to employees' beliefs of how much the organisation appreciates their contribution and concerned about their well-being (Eisenberger et al., 1986). The Organisational Support Theory (OST) (Eisenberger et al., 1986; Eisenberger \& Stinglhamber, 2011) suggests that employees formed a overall perception of how much organisation appreciates their contributions and cares about their well-being. Perceived organisational support emphasised that workers develop a general perception regarding organisation appreciation of their contribution and concerned about their well-being to meet socio-emotional needs and to assess the benefits of increased work effort. Employees' sense of obligation in helping the government to achieve its targets and their level of commitment and expectation of rewards for better performance will increase because of perceived organisational support (Eisenberger et al., 1986; Rhoades \& Eisenberger, 2002). According to previous research, perceived organisational support can be explored from three perspectives: co-workers/peers support, supervisor support, and management support (Woo, 2009). "Organisational support "is not restricted to the organisation only; it covers the agents as well. Agents are those who carry out tasks, such as co-workers or peer and supervisors, are the organisation itself and their action represent those of the organisation; agents' feelings and wishes the feeling and wishes of the organisation (Levinson, 1965).

\subsubsection{Management Support}

Management support generally means support from the organisation, and the most widely used and accepted definition of organisational support was given by Eisenberger et al. (1986). They define "organisational support" as "employees' perception of the degree to which the organisation values their contributions and cares about their well-being". Kiewitz, Restubog, Zagenczyk, and Hochwarter (2009) emphasis on the importance of research on organisational support factors because failure to meet its obligation towards their employees will lead to the decrease in the level of perceived organisational support among its employees. A similar conclusion was made by Ahmed, Wan Ismail, Mohamad Amin, and Ramzan (2012) and Coyle-Shapiro and Conway (2005) when their findings revealed that incentive encouragements offered by the organisation would cause employees to form positive feeling towards organisational support. In short, it is evidenced that there is a strong relationship between incentive encouragement and employees' perception of organisational support. Therefore, it can be deduced that the relationship between an organisation and its employees resulted in employees' perception of organisational support, as noted by Eisenberger et al. 
(1986). The relationship formation is based on the exchanges between employees and the organisation. For support rendered by the organisation, employees give their commitment in return. The basic construct for the antecedents of perceived organisational support is the exchange relation, as described in Social Exchange Theory (SET). According to Blau (1964), exchange relation-social or economic exchange-evolved from future expectations, but with different nature and time frame. Economic exchange is contractual and dependent on a certain time frame. Meanwhile, social exchange is casual, open-ended, and long-term relationships; grounded on an unwritten commitment to "reciprocate" (Blau, 1964; Gouldner, 1960). Ahmed et al. (2012), Chou and Robert (2008) and Woo (2009), explained that perceived organisational support comprises three constructs: co-workers' support, supervisor support, and management support. Thus, this study predicts the relationship between management support and organisational commitment (affective, normative, and continuance commitment), as follows:

H1: Management support will be significantly related to affective commitment

$\mathrm{H} 2$ : Management support will be significantly related to normative commitment

H3: Management support will be significantly related to continuance commitment

\subsubsection{Supervisor Support}

An organisation typically comprises a group of people who strive to achieve a common purpose or goal. Employees are required to interact with relevant parties, such as the management, supervisors, co-workers and subordinates to get things done, of which, among them, supervisors are the dominant party with a certain degree of influence on employees. Supervisors role is bridging the gap between employees and the management (Jokisaari \& Nurmi, 2009). Every action carried out by the supervisors is considered an action of the organisation as supervisors are agents representing the organisation. Eisenberger et al. (1986) stated that employees view an organisation as a person; thus, its actions are deemed a person's actions. Likewise, agents carrying out a task on behalf of the organisation are an organisation themselves; thus, their actions will be the actions of the organisation. According to Levinson (1965), agents' wishes and feelings are the organisation's feelings and wishes. Kottke and Sharafinski (1988), cited evidence from the literature that employees' appraisal from their supervisor or leader or senior, is linked to "supervisor support". The term "supervisor support" is parallel to the opinion of Levinson (1965), who argued that employees view their supervisor positively or negatively or positive, and that supervisor support indicates organisational support. Employees will have a positive perception regarding organisational support if the supervisors are supportive; conversely, an unsupportive supervisor will render a negative perception towards the organisation. Many researchers corroborated this view, such as Rhoades and Eisenberger (2002) and Rhoades, Eisenberger, and Armeli (2001). Supervisors are also a leader; they are expected to be available for the employees, as a leader is towards his or her followers. Employees need supervisors to guide them in performing their tasks, as emphasis by Brown and Duguid (1991). They suggest that leadership consists of skills, internal capabilities, honesty, experience, and personality, with authority and generally accepted by followers and co-workers. Similarly, Harvey, Royal and 
Stout (2003) asserted that the main purpose of leadership is to achieve certain goals. Wayne, Shore and Liden (1997) concluded that supervisor support greatly affected employees' perception towards organisational support. Thus, it is safe to say that employees and their supervisors are in an exchange relationship. The current study takes into account these arguments, and consider management support and supervisor support as the components of the constructs of concept that define perceived organisational support. Thus, this study anticipates that supervisor support is related to organisational commitment (affective, normative, and continuance commitment); hence, the following hypotheses:

H4: Supervisor support will be significantly related to affective commitment

H5: Supervisor support will be significantly related to normative commitment

H6: Supervisor support will be significantly related to continuance commitment

\subsubsection{Co-workers Support}

Eisenberger et al. (1986) argued that employees' perception of an organisation is similar to a human being, and its actions reflect the actions of a human being. Correspondingly, agents who act on behalf of the organisation are themselves the organisation, and their actions are the actions of the organisation. Earlier, Levinson (1965) proposed agents' moods and demands reflect the organisation's moods and demands. The concern showed by the management or employees indicates the government's concern. This notion does not exclusively apply to a leader or supervisor; colleagues or employees are considered agents of the organisation, and a representative of the organisation as well. Accordingly, it can be suggested that the organisation and its employees are having an agency relationship. From an employee standpoint, there are two types of representative or agent of an organisation, namely the leader or supervisor, and peers or co-workers. Therefore, organisational support consists of management or organisation support, supervisor support, and peers or co-workers' support. The cited literature provides evidence that shows peers or co-workers support could positively influence employees' perception of organisational support. Thus, this study proposed the possibility of a relationship between co-workers' support and organisational commitment (affective, normative and continuance commitment); hence, the following hypotheses:

H7: Co-worker support will be significantly related to affective commitment

H8: Co-worker support will be significantly related to normative commitment

H9: Co-worker support will be significantly related to continuance commitment

\section{Data and Methodology}

A pilot study was conducted involving 246 respondents; however, only 234 samples fulfilled all criteria. The questionnaires were distributed to respondents by region within Malaysia, namely Peninsular Malaysia, Sarawak, and Sabah. Data were gathered by means of an online questionnaire and blasted to the oil and gas operators' management, who then disseminated the online questionnaire via Google forms to their permanent offshore employees. A cover 
letter/consent form was included in the survey, which describes the study's purpose to the participants. Participants need to complete the questionnaire as part of the study on employee engagement and perceived organisational support. Participation was strictly voluntary, and they were guaranteed of the confidentiality of their responses. Table 1 presents the respondents' demographic information.

Table 1. Respondent's Demographic information

\begin{tabular}{cccc}
\hline Variable & & Frequency & Per cent $\mathbf{( \% )}$ \\
\hline \multirow{2}{*}{ Gender } & Male & 211 & 90.2 \\
& Female & 23 & 9.8 \\
\hline \multirow{3}{*}{ Marital Status } & Single & 48 & 20.5 \\
& Married & 184 & 78.6 \\
& Widow & 1 & 0.4 \\
& Widower & 1 & 0.4 \\
\hline \multirow{3}{*}{ Education } & Doctorate & 0 & 0.0 \\
& Master & 6 & 2.6 \\
& Degree & 70 & 29.9 \\
& Diploma & 98 & 41.9 \\
& Others & 60 & 25.6 \\
\hline \multirow{2}{*}{ Race } & Malay & 91 & 38.9 \\
& Chinese & 15 & 6.4 \\
& Indian & 2 & 0.9 \\
& Sabah Natives & 71 & 30.3 \\
& Sarawak Natives & 38 & 16.2 \\
Working Tenure & Others & 17 & 7.3 \\
\hline \multirow{2}{*}{ Wess than 2 years } & 30 & 12.8 \\
& From 2 - 5 years & 49 & 20.9 \\
& More than 5 years & 155 & 66.2 \\
\hline
\end{tabular}

\subsection{Conceptual Framework}

The present study aims to investigate the relationship of each dimension of perceived organisational support, which consists of co-workers' support, supervisor support, and management support, with organisational commitment, which comprises affective, normative, and continuance commitment, as illustrates in Figure 1.

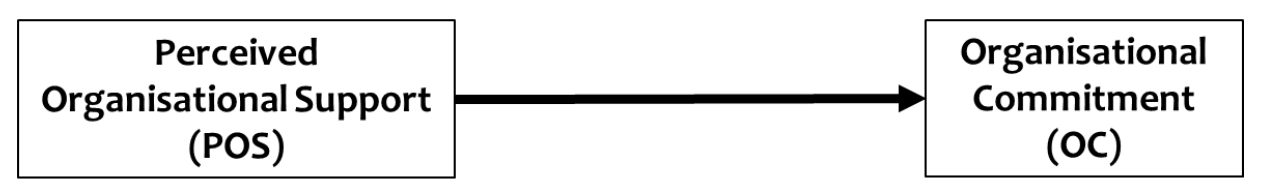

Figure 1. Conceptual framework

\subsection{Estimation Procedure}

There are three parts of the survey questionnaire. Part 1 is to collect the respondents' 


\section{Macrothink}

International Journal of Human Resource Studies ISSN 2162-3058 2020, Vol. 10, No. 4

demographic data. Part 2 is to measure perceived organisational support by using 12 items taken from Rhoades et al. (2001) for management and supervisor support dimensions, and six items were adopted from Hammer, Saksvik, Nytrø, Torvatn, and Bayazit (2004) for co-workers' support dimension. Part 3 is to measure organisational commitment, which contains 23 items that were adapted and adopted from Jaros (2007), and divided into three subscales: affective, normative, and continuance commitment as shown in Table 2.

Table 2. Measurement and sources

\begin{tabular}{ccc}
\hline Construct & Dimension & Source \\
\hline $\begin{array}{c}\text { Organisational } \\
\text { Commitment }\end{array}$ & Affective Commitment & Normative Commitment \\
& Continuance Commitment & \\
\hline Perceived & Management Support & Rhoades and Eisenberger (2002) \\
Organisational & Supervisor Support & Rhoades and Eisenberger (2002) \\
Support & Co-workers Support & Hammer et al. (2004) \\
\hline
\end{tabular}

\subsection{Statistical Analysis}

By using the Partial Least Square (PLS) approach, a two-stage data analysis was conducted. The first stage is the assessment of the reflective, and formative measurement model to determine the items of the measurement relation to the constructs. Stage two is the testing of structural model estimation for hypothesis testing purpose.

\subsection{Measurement Model}

In order to test the measurement reliability and construct validity (i.e., convergent validity and discriminant validity), several analyses were performed. Table 3 and Table 4 show the tests' results, which generally suggest that convergent validity and discriminant validity are adequate.

Table 3. Convergent validity for the reflective measurement model

\begin{tabular}{cccccc}
\hline Variable & Dimension & Item & Loadings & CR & AVE \\
\hline & Affective Commitment & AC1 & 0.805 & 0.925 & 0.607 \\
$($ AC) & AC2 & 0.743 & & \\
& AC3 & 0.677 & & \\
& & AC4 & 0.756 & & \\
Organisational & AC5 & 0.857 & & \\
Commitment & Normative Commitment & AC6 & 0.665 & & \\
& AC) & AC1 & 0.829 & & \\
\cline { 2 - 5 } & & NC2 & 0.718 & 0.942 & 0.699 \\
& & NC3 & 0.820 & & \\
& NC4 & 0.867 & & \\
& NC5 & 0.859 & & \\
& NC6 & 0.858 & & \\
\cline { 2 - 6 } & Continuance Commitment & CC1 & 0.468 & 0.894 & 0.595 \\
& (CC) & CC2 & 0.791 & & \\
\hline
\end{tabular}




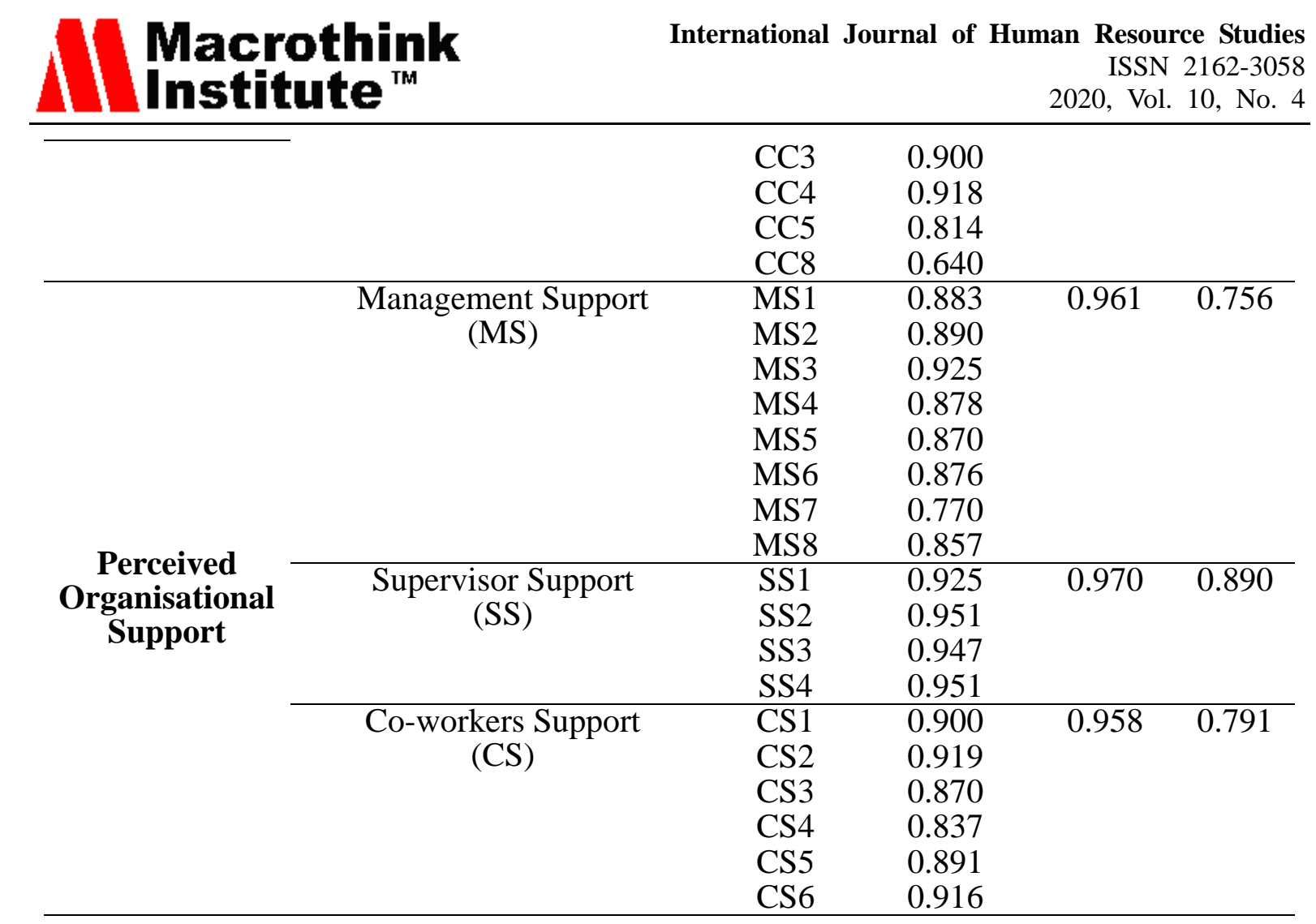

Note: Due to poor loading, items CC6 and CC7 were deleted (Hair, Black, Babin, \& Anderson, 2010, \& Hair, Hult, Ringle, \& Sarstedt, 2014)

Table 3 shows the values of composite reliability that ranged from 0.894 to 0.970 , which were more than the suggested value of 0.70 (Hair et al., 2010; Chin, 1998). The values for average variance extracted (AVE) were within the range of 0.595 to 0.890 (see Table 3), exceeded the recommended threshold value of 0.50 (Hair et al., 2010). Collectively, the results suggest an acceptable construct validity for all constructs in this study.

Table 4. Discriminant validity

\begin{tabular}{c|cccccc}
\hline \multicolumn{2}{c}{ AC } & CC & CS & MS & NC & SS \\
\hline AC & - & & & & & \\
CC & 0.866 & - & & & & \\
CS & 0.456 & 0.461 & - & & & \\
MS & 0.654 & 0.642 & 0.455 & - & & \\
NC & 0.821 & 0.856 & 0.492 & 0.649 & - & \\
SS & 0.478 & 0.405 & 0.470 & 0.642 & 0.451 & - \\
\hline
\end{tabular}

Table 4 provides the outcomes of discriminant validity test where the square root of the values of AVE for each latent variable was higher than the correlation values between the variables. Thus, based on the HTMT criterion, the results indicate that the variables' discriminant validity is adequate, at HTMT $_{90}$ (Gold, Malhotra, \& Segars, 2001).

\subsection{Structural Model}

In this section, the structural model testing will determine whether the data collected support the hypothesised relationships will be deliberated, which begin with the direct effects testing. 
In order to conduct the tests, the constructs' standard errors were obtained by bootstrapping the sample 5000 times (Henseler, Ringle, \& Sinkovics, 2009). The t-test results were generated from the bootstrapping process to determine the path model relationships' significance. The path coefficient (Std. Beta) and the coefficient of determination $\left(\mathrm{R}^{2}\right)$ statistics were used as the indicators. Cohen (1988) suggests to assess $\mathrm{R}^{2}$ values for endogenous latent variables according to the following criteria: 0.26 is substantial, 0.13 is moderate, and 0.02 is weak. Meanwhile, according to Cohen (1988), to assess the effect size, the assessment of the $\mathrm{f}^{2}$ values for endogenous latent variables is based on the subsequent criteria: 0.35 is large, 0.15 is medium, and 0.02 is small. Besides evaluating the magnitude of the $\mathrm{R}^{2}$ values as a criterion of predictive accuracy, $\mathrm{Q}^{2}$ value can be examined as well, whereby $\mathrm{Q}^{2}$ value serves as an indicator for the model's predictive relevance. A PLS-SEM model that shows predictive relevance accurately predicts the indicators' data points in multi-item reflective measurement models and single-item endogenous constructs. For the SEM model, if the $\mathrm{Q}^{2}$ values for a specific reflective endogenous latent variable are bigger than zero, it indicates the predictive relevance of the path model for a certain construct. On the contrary, if the $\mathrm{Q}^{2}$ values are zero or below, it implies a lack of predictive relevance (Hair et al., 2014).

\section{Results}

Based on the results in Table 5, management support is found to be significantly related to all organisational commitment dimensions, namely affective commitment $(\beta=0.497$, $t$-value $=$ 5.317, $\mathrm{p}<0.05)$, normative commitment $(\beta=0.501$, $\mathrm{t}$-value $=7.406, \mathrm{p}<0.05)$ and continuance commitment $(\beta=0.529$, $\mathrm{t}$-value $=6.369, \mathrm{p}<0.05)$. In addition, supervisor support is found to be insignificantly related to all organisational commitment dimensions, namely affective commitment $(\beta=0.064$, t-value $=0.678, \mathrm{p}>0.05)$, normative commitment $(\beta=0.009, \mathrm{t}$-value $=0.140, \mathrm{p}>0.05)$ and continuance commitment $(\beta=-0.045, \mathrm{t}$-value $=$ $0.488, \mathrm{p}>0.05)$. Furthermore, co-workers support is found to be significantly related to all organisational commitment dimensions, namely affective commitment $(\beta=0.203$, t-value $=$ 2.687, $\mathrm{p}<0.05)$, normative commitment $(\beta=0.247, \mathrm{t}$-value $=3.581, \mathrm{p}<0.05)$ and continuance commitment $(\beta=0.232$, $\mathrm{t}$-value $=3.238, \mathrm{p}<0.05)$. Thus, all six hypotheses $(\mathrm{H} 1$, H2, H3, H7, H8 and H9) are supported, while H4, H5, and H6 are not supported.

Table 5. Hypothesis Testing for Direct Effect

\begin{tabular}{ccccccccc}
\hline \multirow{2}{*}{ HYPOTHESIS } & DIRECT & $\begin{array}{c}\text { STD. } \\
\text { EFFECT }\end{array}$ & $\begin{array}{c}\text { STD. } \\
\text { BERA }\end{array}$ & $\begin{array}{c}\text { T- } \\
\text { ERROR }\end{array}$ & $\begin{array}{c}\text { P- } \\
\text { VALUES }\end{array}$ & $\begin{array}{c}\text { DALCISION } \\
\text { VALC }\end{array}$ & $\begin{array}{c}\text { 5\% } \\
\text { LL }\end{array}$ & $\begin{array}{c}\text { 95\% } \\
\text { UL }\end{array}$ \\
\hline $\mathbf{H 1}$ & $\mathrm{MS} \rightarrow \mathrm{AC}$ & 0.497 & 0.094 & 5.317 & $0.000^{*}$ & Supported & 0.334 & 0.645 \\
$\mathbf{H 2}$ & $\mathrm{MS} \rightarrow \mathrm{NC}$ & 0.501 & 0.068 & 7.406 & $0.000^{*}$ & Supported & 0.388 & 0.609 \\
$\mathbf{H 3}$ & $\mathrm{MS} \rightarrow \mathrm{CC}$ & 0.529 & 0.083 & 6.369 & $0.000^{*}$ & Supported & 0.392 & 0.666 \\
$\mathbf{H 4}$ & $\mathrm{SS} \rightarrow \mathrm{AC}$ & 0.064 & 0.097 & 0.678 & 0.249 & Not Supported & -0.093 & 0.227 \\
$\mathbf{H 5}$ & $\mathrm{SS} \rightarrow \mathrm{NC}$ & 0.009 & 0.080 & 0.140 & 0.444 & Not Supported & -0.120 & 0.143 \\
$\mathbf{H 6}$ & $\mathrm{SS} \rightarrow \mathrm{CC}$ & -0.045 & 0.090 & 0.488 & 0.313 & Not Supported & -0.182 & 0.114 \\
$\mathbf{H 7}$ & $\mathrm{CS} \rightarrow \mathrm{AC}$ & 0.203 & 0.073 & 2.687 & $0.004^{*}$ & Supported & 0.076 & 0.315 \\
$\mathbf{H 8}$ & $\mathrm{CS} \rightarrow \mathrm{NC}$ & 0.247 & 0.068 & 3.581 & $0.000^{*}$ & Supported & 0.128 & 0.351 \\
$\mathbf{H 9}$ & $\mathrm{CS} \rightarrow \mathrm{CC}$ & 0.232 & 0.070 & 3.238 & $0.001^{*}$ & Supported & 0.109 & 0.340 \\
\hline
\end{tabular}

Note: * p-value<0.05, t-value>1.645 (one-tailed) as per Hair et al., (2017) 


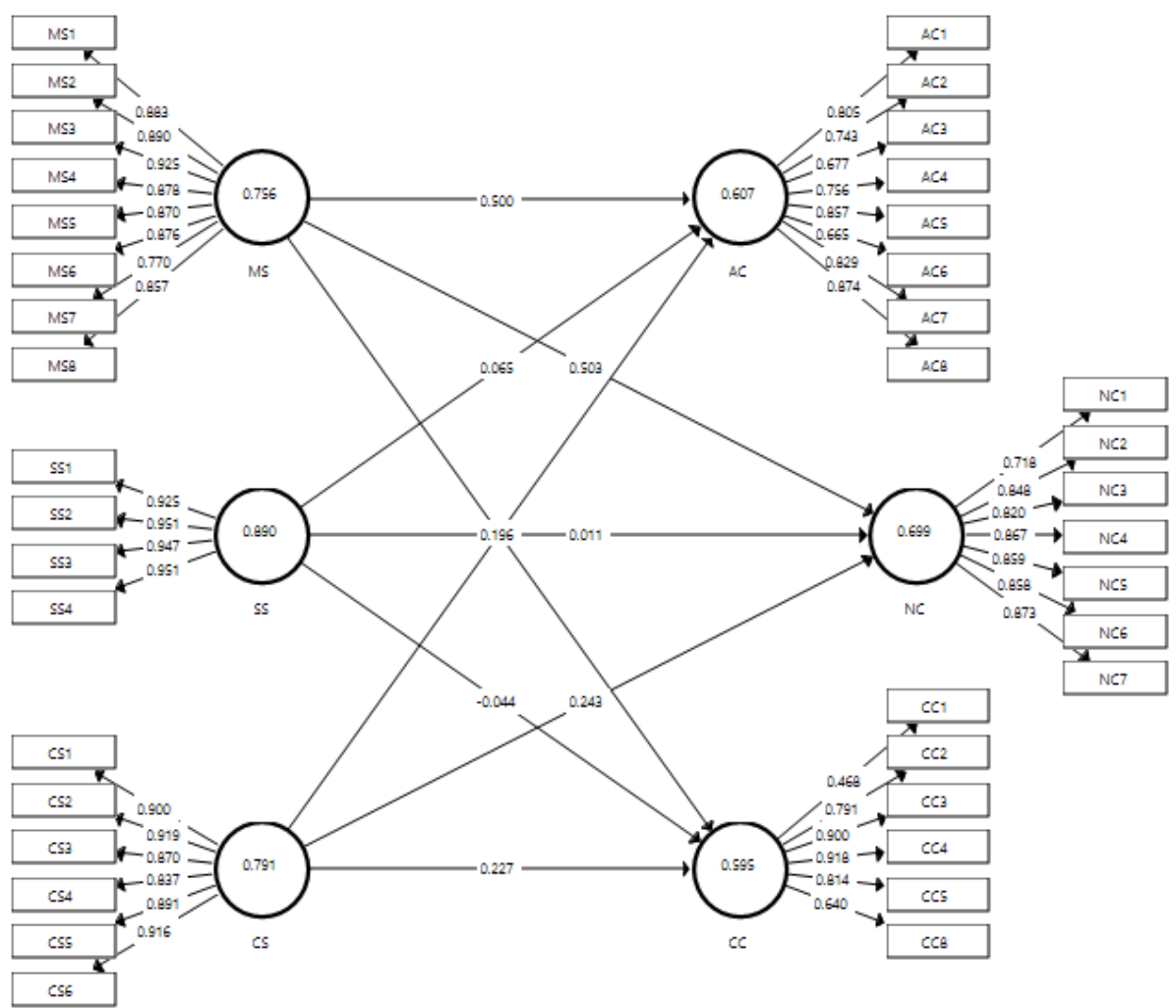

Figure 2. The PLS Structural Model

Table 6. Effect size and Predictive Relevance

\begin{tabular}{c|ccccc}
\hline HYPOTHESIS & DIRECT EFFECT & $\mathbf{F}^{\mathbf{2}}$ & $\mathbf{R}^{\mathbf{2}}$ & VIF & $\mathbf{Q}^{\mathbf{2}}$ \\
\hline $\mathbf{H 1}$ & $\mathrm{MS} \rightarrow \mathrm{AC}$ & 0.258 & 0.422 & 1.695 & 0.402 \\
$\mathbf{H 2}$ & $\mathrm{MS} \rightarrow \mathrm{NC}$ & 0.262 & 0.421 & 1.696 & 0.406 \\
$\mathbf{H 3}$ & $\mathrm{MS} \rightarrow \mathrm{CC}$ & 0.278 & 0.395 & 1.695 & 0.375 \\
$\mathbf{H 4}$ & $\mathrm{SS} \rightarrow \mathrm{AC}$ & 0.004 & & 1.719 & \\
$\mathbf{H 5}$ & $\mathrm{SS} \rightarrow \mathrm{NC}$ & 0.000 & & 1.719 & \\
$\mathbf{H 6}$ & $\mathrm{SS} \rightarrow \mathrm{CC}$ & 0.002 & & 1.719 & \\
$\mathbf{H 7}$ & $\mathrm{CS} \rightarrow \mathrm{AC}$ & 0.051 & & 1.322 & \\
$\mathbf{H 8}$ & $\mathrm{CS} \rightarrow \mathrm{NC}$ & 0.078 & & 1.322 & \\
H9 & $\mathrm{CS} \rightarrow \mathrm{CC}$ & 0.065 & & 1.322 & \\
\hline
\end{tabular}

As shown in Table $6, \mathrm{R}^{2}$ values are beyond 0.26 , indicating their significance. For affective commitment, the $\mathrm{R}^{2}$ is 0.422 , suggesting that $42.2 \%$ of the variance in affective commitment can be explained by perceived organisational support dimensions. Additionally, the $\mathrm{R}^{2}$ for normative commitment is 0.421 , suggesting that $42.1 \%$ of the variance in normative commitment can be explained by perceived organisational support dimensions. Similarly, for continuance commitment, the $\mathrm{R}^{2}$ value is 0.395 , suggesting that $39.5 \%$ of the variance in continuance commitment can be explained by perceived organisational support dimensions. In addition, with respect to effect size, the $\mathrm{f}^{2}$ values shows medium to large effect size for management support $\left(\mathrm{f}^{2}=0.258-0.278\right)$. Meanwhile, the $\mathrm{f}^{2}$ values shows a small effect size for supervisor support $\left(f^{2}=0.000-0.004\right)$ and co-workers support $\left(f^{2}=0.051-0.078\right)$. 
Given the range of $\mathrm{Q}^{2}$ values for all organisational commitment dimensions, namely affective, normative and continuance commitment, is between 0.375 and 0.406 , exceeding the zero value, the result renders further support to the endogenous constructs' predictive relevance.

\section{Discussion}

Based on the findings, all the hypotheses except for H4, H5 and H6 gave the expected results; hence, supporting the notion that by having a high level of perceived organisational support, employees will reciprocate leading to the increased level of organisational commitment. In general, the study's findings highlighted that there is a lack of supervisor support for offshore employees, which lead to an insignificant relationship in all organisational commitment dimensions. This finding is supported by Harun, Salleh, Memon, Baharom, and Abdullah (2014), whereby their study also found the existence of a social gap between employees of a lower level and those in executive level at the site, which consist of Platform Supervisor, Senior Operation Supervisor, and Operation Supervisor. Moreover, the study highlighted that supervisor support has the smallest effect size compared with management support and co-workers' support. Management support has a small to medium effect size towards organisational commitment, which corroborate the finding by Eisenberger et al. (1986) that higher management will have higher impact compared with lower management. Co-workers support has a small effect size but higher than supervisor support; this finding is in a similar vein with the research finding by Eva, Meacham, Newman, Schwarz, and Tham (2019) that co-workers can be used to supplement the lack of supervisor when required. Due to the offshore environment, employees tend to share their concerns or issues with peers instead of supervisors. Thus, supervisors who are mostly at the offshore need to be seen as providing adequate support while performing his duty. Support may be offered through various ways, such as listening to employees' idea or concern, providing necessary resources for them to complete a task efficiently and safely, offering assurance, especially on the safety aspect while carrying out their duty on the platform, and promoting work-life balance to ensure employees mental health is cared for. As with other studies, this study has encountered several limitations. Data were collected among employees working at the oil and gas offshore facilities within Malaysia. Thus, the findings' generalisability might apply to other industries in Malaysia. Since the study was conducted among employees in the offshore environment, the context of the study is also different from that of employees working in the onshore environment. Therefore, it is proposed that future research should replicate this study in other industries to generalise the findings further. Also, for future studies, it will be interesting to explore employee engagement role in mediating the relationship between perceived organisational support and organisational commitment at offshore facilities.

\section{References}

Addae, H. M., Praveen Parboteeah, K., \& Velinor, N. (2008). Role stressors and organisational commitment: Public sector employment in St Lucia. International Journal of Manpower, 29(6), 567-582. https://doi.org/10.1108/01437720810904220

Aggarwal-Gupta, M., Vohra, N., \& Bathnagar, D. (2010). Perceived organisational support and organisational commitment: the mediational influence of psychological well-being. Journal of 
Business and Management, 16(2), 105-124. https://doi.org/10.1093/infdis/jiu023

Ahmed, I., Wan Ismail, W. K., Mohamad Amin, S., \& Ramzan, M. (2012). A look at social exchange at work: A literature survey approach. World applied Sciences Journal, 19(7), 951-956. https://doi.org/10.5829/idosi.wasj.2012.19.07.2297

Allen, N. J., \& Meyer, J. P. (1990). The measurement and antecedents of affective, continuance and normative commitment to the organisation. Journal of Occupational Psychology, 63, 1-18. https://doi.org/10.1111/j.2044-8325.1990.tb00506.x

Aubé, C., Rousseau, V., \& Morin, E. M. (2007). Perceived organisational support and organisational commitment: The moderating effect of locus of control and work autonomy. Journal of Managerial Psychology, 22(5), 479-495. https://doi.org/10.1108/02683940710757209

Beardwell, J., \& Thompson, A. (Eds.) (2014). Human resource management: A contemporary approach (7th ed.). Harlow: Pearson Education.

Becker, H. (1960). Notes on the concept of commitment. American Journal of Sociology, 66(1), 32-40. https://doi.org/10.1086/222820

Blau, G. J., \& Boal, K. B. (1987). Conceptualising how job involvement and organisational commitment affect turnover and absenteeism. Academy of Management Review, 12(2), 288-300. https://doi.org/10.5465/AMR.1987.4307844

Blau, P. M. (1964). Exchange and power in social life. New York: Wiley.

Brown, J. S., \& Duguid, P. (1991). Organisational learning and communities-of-practice: Toward a unified view of working, learning, and innovation. Organization Science, 2(1), 40-57. https://doi.org/10.1287/orsc.2.1.40

Buchanan, B. II. (1974). Building organisational commitment: The socialisation of managers in work organisations. Administrative Science Quarterly, 19(4), 533-546. https://doi.org/10.2307/2391809

Chin, W. W. (1998). The partial least squares approach to structural equation modeling. In G. A. Marcoulides (Ed.), Modern methods for business research (pp. 295-336). Mahwah, NJ: Lawrence Erlbaum Associates.

Chou, R. J., \& Robert, S. A. (2008). Workplace support, role overload and job satisfaction, direct care workers in assisted living. Journal of Health and Social Behaviour, 49(2), 208-222. https://doi.org/10.1177/002214650804900207

Cohen, J. (1988). Statistical power analysis for the behavioral sciences (2nd ed.). Hillsdale, NJ: Lawrence Erlbaum Associates.

Coyle-Shapiro, J. A-M., \& Conway, N. (2005). Exchange relationships: Examining psychological contracts and perceived organisational support. Journal of Applied Psychology, 90(4), 774-781. https://doi.org/10.1037/0021-9010.90.4.774

Currie, P., \& Dollery, B. (2006). Organisational commitment and perceived organisational support in the NSW Police. Policing: An International Journal, 29(4), 741-756. 
https://doi.org/10.1108/13639510610711637

Dunham, R. B., Grube, J. A., \& Castañeda, M. B. (1994). Organisational commitment: The utility of an integrative definition. Journal of Applied Psychology, 79(3), 370-380. https://doi.org/10.1037/0021-9010.79.3.370

Eisenberger, R., Huntington, R., Hutchison, S., \& Sowa, D. (1986). Perceived organisational support. Journal of Applied Psychology, 71(3), 500-507. https://doi.org/10.1037/0021-9010.71.3.500

Eisenberger, R., \& Stinglhamber, F. (2011). Perceived organisational support: Fostering enthusiastic and productive employees. Washington, DC: American Psychological Association.

Eva, N., Meacham, H., Newman, A., Schwarz, G., \& Tham, T. L. (2019). Is co-worker feedback more important than supervisor feedback for increasing innovative behavior?. Human Resource Management, 58(4), 383-396. https://doi.org/10.1002/hrm.21960

Farid, H., Izadi, Z., Ismail, I. A., \& Alipour, F. (2015). Relationship between quality of work-life and organisational commitment among lecturers in a Malaysian public research university. Social Science Journal, 52(1), 54-61. https://doi.org/10.1016/j.soscij.2014.09.003.

George, J. M., Reed, T. F., Ballard, K. A., Colin, J., \& Fielding, J. (1993). Contact with AIDS patients as a source of work-related distress: Effects of organisational and social support. Academy of Management, 36(1), 157-171. https://doi.org/10.2307/256516

Gold, A. H., Malhotra, A., \& Segars, A. H. (2001). Knowledge management: An organisational capabilities perspective. Journal of Management Information Systems, 18(1), 185-214. https://doi.org/10.1080/07421222.2001.11045669

Gouldner, A.W. (1960). The norm of reciprocity: A preliminary statement. American Sociological Review, 25(2), 161-178. https://doi.org/10.2307/2092623

Hackett, R. D., Bycio, P., \& Hausadorf, P. A. (1994). Further assessment of Meyer and Allen's 1991 three-components model of organisational commitment. Journal of Applied Psychology, 79(1), 15-23. https://doi.org/10.1037/0021-9010.79.1.15

Hair, J. F., Ringle, C. M., \& Sarstedt, M. (2013). Partial least squares structural equation modeling: Rigorous applications, better results and higher acceptance. Long Range Planning, 46, 1-12. https://doi.org/10.1016/j.lrp.2013.01.001

Hair, J. F., Jr., Black, W. C., Babin, B. J., \& Anderson, R. E. (2010). Multivariate data analysis (7th ed.). Upper Saddle River, NJ: Pearson Education.

Hair. J. F., Jr., Hult, G. T. M., Ringle, C. M., \& Sarstedt, M. (2014). A primer on partial least squares structural equation modelling (PLS-SEM). Thousand Oaks: SAGE.

Hall, D. T., Schneider, B., \& Nygren, H. T. (1970). Personal factors in organisational identification. Administrative Science Quarterly, 15(2), 176-190. https://doi.org/10.2307/2391488

Hammer, T. H., Saksvik, P. Ø., Nytrø, K., Torvatn, H., \& Bayazit, M. (2004). Expanding the psychosocial work environment: Workplace norms and work-family conflict as correlates of stress 
and health. Journal of Occupational Health Psychology, 9(1), 83-97. https://doi.org/10.1037/1076-8998.9.1.83

Harun, H., Salleh, R., Memon, M. A., Baharom, M. N. R., \& Abdullah, A. (2014). Job satisfaction, organisational commitment and stress among offshore oil and gas platform employees. Asian Social Science, 10(11), 28-32. https://doi.org/10.5539/ass.v10n11p28

Harvey, S., Royal, M., \& Stout, D. (2003). Instructor's transformational leadership: University student attitudes and ratings. Psychological Reports, 92(2), 395-402. https://doi.org/10.2466/PR0.92.2.395-402

Henseler, J., \& Fassott, G. (2010). Testing moderating effects in PLS path models: an illustration of available procedures. In V. Esposito Vinzi, W. Chin, J. Henseler \& H. Wang H. (Eds.), Handbook of Partial Least Squares. Springer Handbooks of Computational Statistics (pp. 713-735). Springer, Berlin, Heidelberg. https://doi.org/10.1007/978-3-540-32827-8_31

Henseler, J., Ringle, C. M., \& Sinkovics, R. R. (2009). The use of partial least squares path modeling in international marketing. In R. R. Sinkovics \& P. N. Ghauri (Eds.), New Challenges to International Marketing (Advances in International Marketing (Vol. 20, pp. 277-319). Bingley: Emerald Group Publishing Limited. https://doi.org/10.1108/S1474-7979(2009)0000020014

Iles, P., Forster, A., \& Tinline, G. (1996). The changing relationships between work commitment, personal flexibility and employability: An evaluation of a field experiment in executive development. Journal of Managerial Psychology, 11(8) 18-34. https://doi.org/10.1108/02683949610150033

Jaros, S. J. (2007). Meyer and Allen model of organisational commitment: Measurement issues. Icfai Journal of Organizational Behavior, 6(4), 7-25. Retrieved from https://www.academia.edu/35387821

Jokisaari, M., \& Nurmi, J.-E. (2009). Change in newcomers' supervisor support and socialisation outcomes after organisational entry. Academy of Management Journal, 52(3), 527-544. https://doi.org/10.5465/AMJ.2009.41330971

Kanter, R. M. (1968). Commitment and social organisation: A study of commitment mechanisms in utopian communities. American Sociological Review, 33(4), 499-517. https://doi.org/10.2307/2092438

Kiewitz, C., Restubog, S. L. D., Zagenczyk, T., \& Hochwarter, W. (2009). The interactive effects of psychological contract breach and organisational politics on perceived organisational support: Evidence from two longitudinal studies. Journal of Management Studies, 46(5), 806-834. https://doi.org/10.1111/j.1467-6486.2008.00816.x

Klein, H. J., Becker, T. E., \& Meyer, J. P. (Eds.). (2009). Commitment in organisations: Accumulated wisdom and new directions. New York: Routledge/Taylor \& Francis Group.

Kottke, J. L., \& Sharafinski, C. E. (1988). Measuring perceived supervisory and organisational support. Educational and Psychological Measurement, 48(4), 1075-1079. https://doi.org/10.1177/0013164488484024

Kwantes, C. (2009). Culture, job satisfaction and organisational commitment in India and the United 
States. Journal of Indian Business Research, 1(4), 196-212. https://doi.org/10.1108/17554190911013265

Levinson, H. (1965). Reciprocation: The relationship between man and the organisation. Administrative Science Quarterly, 9(4), 370-390. https://doi.org/10.2307/2391032

March, J. G., \& Simon, H. A. (1958). Organisations. New York: Wiley.

Meyer, J. P., \& Allen, N. J. (1991). A three-component conceptualisation of organisational commitment. Human Resource Management Review, 1(1), 61-89. https://doi.org/10.1016/1053-4822(91)90011-Z

Meyer, J. P., \& Allen, N. J. (1997). Advanced topics in organisation behavior series. Commitment in the workplace: Theory, research, and application. Thousand Oaks, CA: Sage Publications.

Meyer, J. P., Allen, N. J., \& Smith, C. A. (1993). Commitment to organisations and occupations: Extension and test of a three-component conceptualisation. Journal of Applied Psychology, 78(4), 538-551. https://doi.org/10.1037/0021-9010.78.4.538

Murray, L. P., Gregoire, M. B., \& Downey, R. G. (1991). Organisational commitment of management employees in restaurant operations. Journal of Hospitality \& Research, 14(2), 339-348. https://doi.org/10.1177/109634809001400236

Newstrom, J. W. (2015). Organisational behavior: Human behavior at work. New York, NY: McGraw-Hill Education

Okpara, J. O. (2004, June). Job satisfaction and organisational commitment: Are there differences between American and Nigerian managers employed in the US MNCs in Nigeria? Paper presented at the Academy of Business \& Administrative Sciences (ABAS) International Conference, Montreux.

Rhoades, L., Eisenberger, R., \& Armeli, S. (2001). Affective commitment to the organisation: The contribution of perceived organisational support. Journal of Applied Psychology, 86(5), 825-836. https://doi.org/10.1037/0021-9010.86.5.825

Rhoades, L., \& Eisenberger, R. (2002). Perceived organisational support: A review of the literature. Journal of Applied Psychology, 87(4), 698-714. https://doi.org/10.1037/0021-9010.87.4.698

Roussenau, D. M. (1995). Promises in action: Psychological contracts in organisations. Newbury Park, CA: Sage.

San Martín, S. (2008). Relational and economic antecedents of organisational commitment. Personnel Review, 37(6), 589-608. https://doi.org/10.1108/00483480810906856

Scholl, R. W. (1981). Differentiating organisational commitment from expectancy as a motivating force. Academy of Management Review, 6(4), 589-599. https://doi.org/10.2307/257637

Shore, L. M., \& Tetrick, L. E. (1991). A construct validity study of the survey of perceived organisational support. Journal of Applied Psychology, 76(5), 637-643. https://doi.org/10.1037/0021-9010.76.5.637

Suliman, A., \& Iles, P. (2000). Is continuance commitment beneficial to organisations? 


\section{Macrothink}

International Journal of Human Resource Studies

ISSN 2162-3058 2020, Vol. 10, No. 4

Commitment-performance relationship: A new look. Journal of Managerial Psychology, 15(5), 407-422. https://doi.org/10.1108/02683940010337158

Swailes, S. (2002). Organisational commitment: A critique of the construct and measures. International Journal of Management Reviews, 4(2), 155-178. doi:10.1111/1468-2370.00082

Wayne, S. J., Shore, L. M., \& Liden, R. C. (1997). Perceived organisational support and leader-member exchange. A social exchange perspective. Academy of Management Journal, 40(1), 82-111. https://doi.org/10.2307/257021

Wiener, Y., \& Gechman, A. S. (1977). Commitment: A behavioral approach to job involvement. Journal of Vocational Behavior, 10(1), 47-52. https://doi.org/10.1016/0001-8791(77)90041

Woo, B. (2009). Cultural effects on work attitudes and behaviors: The case of American and Korean fitness employees (Doctoral dissertation, Ohio State University). Retrieved from http://rave.ohiolink.edu/etdc/view?acc_num=osu1241612067

Yousef, D. A. (2000). Organisational commitment: A mediator of the relationships of leadership behavior with job satisfaction and performance in a non-western country. Journal of Managerial Psychology, 15(1), 6-24. https://doi.org/10.1108/02683940010305270

\section{Copyright Disclaimer}

Copyright for this article is retained by the author(s), with first publication rights granted to the journal.

This is an open-access article distributed under the terms and conditions of the Creative Commons Attribution license (http://creativecommons.org/licenses/by/4.0/). 